\title{
The RELATIONSHIP BETWEEN ESERVICE QUALITY, EVALUE, ESATISFACTION AND ELOYALTY IN ONLINE TOURISM PORTALS
}

K Wood and $\mathrm{CH}$ van Heerden

Department of Marketing and Communication Management, University of Pretoria

\begin{abstract}
Customer satisfaction and loyalty are important drivers of business profits. In the online arena, acquisition costs are high, switching costs are low, the service encounter is non-personal and the Internet is often used only as a source of information. The aim of this article is to determine the relationship between critical eService quality elements utilised in online tourism portals in order to establish eLoyalty. The target population of this study was South African tourism accommodation establishments who advertised on online tourism portals during 2005. A personalised branded HTML email with a clickable link to the online survey was mailed to all respondents. One hundred and nine valid responses were received. A multi-item questionnaire was used to measure the relationship between eService quality, eValue, eSatisfaction and eLoyalty pertaining to online tourism portals utilised by the respondents. The findings imply that online tourism portals would increase their eLoyalty (and thus increase profits) if they first satisfied their suppliers' needs by providing them with a secure, visually pleasing user interface with which they could identify. Secondly, there is a need for online tourism portals to provide services that add value, making it easy for suppliers to add and change details on their own pages, as well as ensuring that their suppliers receive a substantial income stream through the portal.
\end{abstract}

Abstract

JEL M31

1

\section{Introduction}

The Internet provides unlimited information access to anyone with an Internet connection. Companies with an online presence realise that merely being online does not guarantee 'hits', 'traffic' or profit. Online portals have begun to play a major role in filling the gap between an overwhelming amount of information and a trustworthy source of products and services. They are also responsible for adding tangible value to the companies they represent. The challenge for portals is that, on the one hand, they have to create a sustainable customer base in an environment where Internet users can easily find and evaluate alternatives, while, on the other hand, they have to satisfy the suppliers from whom they receive substantial revenue (Gummerus, Liljander, Pura \& Van Riel, 2004: 175).
Most tourism portals obtain their revenue from annual or monthly advertising fees, or from a commission-based percentage. In order to keep revenue streaming in, portals have to first achieve a critical mass in terms of obtaining sufficient income from suppliers to cover their marketing expenditure. It is a vicious circle; if they do not spend enough on marketing to increase leads to suppliers, the possibility of switching to another portal might be an easy and cost-effective decision for the suppliers. Acquiring customers on the Internet is very expensive. Jiang and Rosenbloom (2005: 151) stated that the Boston Consulting Group estimates a cost of about $\$ 82$ to acquire a new customer for Internet-only retailers, compared to $\$ 38$ for store-based retailers and $\$ 11$ for catalogue-based retailers. Keating, Rugimbana and Quazi (2003: 217) challenged the view that new customers should be constantly acquired when they pointed out that the 'dotcom crash' 
of the 1990s was the consequence largely of a preoccupation with customer acquisition, while at the same time there was a failure to recognise the importance of delivering good service and nurturing customer relations.

But Reichheld and Schefter (2000: 106) argue that the cost of serving loyal e-customers falls as the volume of their purchases rises and when the relationships get stronger. In an apparel e-tailing study, they found that the customer acquisition cost is 20 per cent to 40 per cent higher for pure Internet companies, compared to that of traditional retailers, who have both physical and online stores. But, even though this demonstrates higher losses in the early stages of the relationship, it was found that the e-customers are likely to spend twice as much during months 24 to 30 as they did during the first six months. This phenomenon is explained in a study by Reichheld, Markey and Hopton (2000: 173), who state that cyber customers are more willing to be loyal to reduce the risks of online shopping. The probability that they will stay with an online vendor is higher once they are satisfied. Results from Bain \& Company (in Clarke, 2001: 161) show that online retailers lose money on one-time shoppers. They point out that online grocers have to retain customers for 18 months just to break even. Further, they found that repeat customers spend more heavily as time goes by: customers were found to spend over a fifth more in months $31-36$ than they did in months 1 to 6 . It is therefore crucially important for online retailers to focus on keeping their current clients satisfied.

Another difficulty in use of the web is that online search engines make price comparisons extremely easy for users when they compare the benefits of competing services. Alba, Lynch, Weitz, Janiszewski, Lutz, Sawyer and Wood (1997: 45) found that the relatively low costs of Internet search mean that customers become less price-tolerant. However, Trocchia and Janda (2003: 249) reason that low price or even quick delivery might not be enough to attract and retain customers. In an online wine study, Lynch and Ariely (2000: 100) found that consumers became less price-sensitive and more loyal when the level of quality information on the site increased, or when the product was unique. Kung, Monroe and Cox (2002: 277) report that Borders.com, Barnes \& Noble.com and Amazon.com all charge substantially higher online prices compared to other online retailers, so price sensitivity is affected by the strength of the relationship with their existing customer base enjoyed by these well-known online retailers (Lee-Kelley, Gilbert \& Mannicom, 2003: 245).

To encourage repeat purchases and build customer loyalty, Zeithaml (2002: 135) suggests that companies need to shift the focus of ebusiness from eCommerce to eService, so that the focus will be distributed over all cues and encounters that occur before, during and after a transaction. To date, little research has focused on online portals and their suppliers, and most current research concentrates on methods that measure the perceptions of the general Internet users. It has therefore become important to find answers to questions on how suppliers evaluate online portals; and in particular to analyse relationships between eService quality, eValue, eSatisfaction and eLoyalty from the perspective of service providers who utilise portals to interact with customers. The aim of this article is to provide insight into how tourism portals can create loyal suppliers and to investigate whether a model can be created that includes the most important variables impacting on eLoyalty. The article will also focus on creating reliable eService quality dimensions specifically for the tourism portal industry.

The rest of the article is structured as follows: first, it reviews the existing literature and a number of hypotheses on how eService, eQuality, eValue, eSatisfaction and eLoyalty are derived, and the relationship between them considered. Secondly, the research methodology and data techniques are discussed. A presentation and discussion of the results follow, whereby a structural model is proposed. Finally the managerial implications, limitations and suggestions for future research are presented.

\section{2}

\section{Literature review and hypotheses}

Customer satisfaction and ultimately customer loyalty are important drivers of business profits. 
The challenge is particularly difficult in the online arena, where acquisition costs are high, switching costs are low, the service encounter is non-personal and some Internet users use the Internet as a source of information only.

Studies relating to online constructs in the tourism context are limited to hotels, most notably Lee and $\mathrm{Hu}$ (2004), who studied ecomplaints at hotels and Miller (2004), who reported on eLoyalty building of lodging brands.

\section{1 eService quality}

According to Zeithaml (2002: 135), the most experienced and successful companies using the Internet are realising that the key determinants of success or failure are not merely web presence or low price. Instead these companies focus on delivering superior eService quality. Striving for an online competitive advantage means that eService quality improvement initiatives should begin with defining the customers' needs and preferences (Yang, Ahmed, Ghingold, Boon, Mei \& Hwa, 2003: 12). If online retailers understood which elements were used by customers to judge quality, they could take appropriate action and remedy service failures (Jun, Yang \& Kim, 2004: 835). Earlier research by Bitner (1992: 65) suggests that contextual cues are associated with eService quality. Contextual cues provide meaningful, nonverbal, quality communication and provide a proxy for judging product/service quality (Lassar \& Dandapani, 2003: 39; Storey \& Easingwood, 1996: 34). Relating this to the online world, Gummerus et al. (2004: 177) defined eService quality as the consumer's evaluation of process and outcome quality of the interaction with a service provider's electronic channels.

Previous research has investigated the link between Service Quality and Satisfaction and most has found that there is first a statistically strong relationship between the two constructs, and secondly that Service Quality has a positive influence on Satisfaction (Heskett, Jones, Loveman, Sasser \& Schlesinger, 1994: 168; Storbacka, Strandvik \& Grönroos, 1994: 24; Sureshchandar, Rajendran \& Anantharaman, 2002: 372). Quality does not improve unless measured (Reichheld \& Sasser, 1990: 105), but, as yet, there is no consensus on the exact nature or number of Service Quality dimensions that customers consider when evaluating eServices (Zeithaml, Parasuraman \& Malhotra, 2002:371). The Internet has also influenced the Quality dimension to such extent that some elements rely strongly on the capabilities of technology to make the eService encounter successful (Olson \& Boyer, 2005: 7). This article therefore includes those eService Quality dimensions discovered in previous studies that fit the tourism portal requirements best. These have been combined with some new portal-specific items. The five chosen dimensions are User Interface, Security, Responsiveness, Customisation and Value-add services.

\section{User Interface}

The User Interface is a key determinant of online Service Quality (Grönroos, Heinonen, Isoniemi \& Lindholm, 2000: 249). The quality of the User Interface is defined as the technical functionality of the site and its design, and offers tangible cues for customers as to those on which they can base their assessment of the provider's trustworthiness (Gummerus et al., 2004: 177). Stanford, Tauber, Fogg and Marable (2002) found that consumers tended to rely heavily on overall visual design when assessing websites. This included layout, typography and colour schemes.

Site aesthetics and layout are therefore important sub-variables of the user interface. Numerous studies have confirmed this, including those of Gummerus et al. (2004), Madu and Madu (2002), Ribbink, Van Riel, Liljander and Streukens (2004), Yang, Peterson and Cai (2003) and Wolfinbarger and Gilly (2003). However, Johnston (1997: 112) found in a retail banking study that overall aesthetics is one of the most important aspects of determining customer dissatisfaction.

An attractive website creates an online environment that is more effective in facilitating website navigation (Semeijn, Van Riel, Van Birgelen \& Streukens, 2005: 183). The concept of website navigation includes not only the physical buttons on the site, but also the ease with which the user is able to navigate it (Bansal, 
McDougall, Dikolli \& Sedatole, 2004; Jun et al., 2004; Kaynama \& Black, 2000; Reibstein, 2002). Previous research by Jayawardhena and Foley (2000: 27) showed that eSatisfaction was dependent on the User Interface features of design and navigation, which leads to the following hypothesis:

$\mathrm{H}_{1}$ : The User Interface dimension of eService Quality will positively influence eSatisfaction.

\section{Security}

Assuring sufficient Security is critical as far as online transactions and sharing personal information are concerned (Jayawardhena \& Foley, 2000; Madu \& Madu, 2002; Yoo \& Donthu, 2001). Customers are unwilling to bond with online services when there is no confidence in the provider's competency and honesty (Gummerus et al., 2004: 175). Users therefore want a highly visible privacy policy that tells them precisely how the company will use their data (Ha, 2004: 336). This policy must be written in simple, clear, unambiguous language, and must convey trust in the system (Madu \& Madu, 2002: 256). The actions of partners and advertisers should also be regulated in terms of their privacy and security policies, in order to protect the online portal's reputation (Gummerus et al., 2004: 183). In contrast, research by Jun et al. (2004: 834) showed that Security does not have a significant influence on Satisfaction, and Johnston (1997: 113) also stated that Security is more likely to be a highly dissatisfying factor. In order to test this, the following hypothesis is stated:

$\mathrm{H}_{2}$ : The Security dimension of eService Quality will positively influence eSatisfaction.

\section{Responsiveness}

Jun et al. (2004: 832) report that online customers are longing for personalised attention from their online retailers. The Responsiveness dimension is the only eService Quality dimension consisting of one-on-one personalised contact when it comes to Internet-only retailers. Responsiveness represents the service provider's ability to respond quickly to requests and suggestions, and to provide assistance for customers when there are problems (Gummerus et al., 2004: 177). They also add that, in responding quickly to customer requests, companies can show that they are customer-orientated and benevolent.

According to Ribbink et al. (2004: 448), Responsiveness generally has a positive influence on eSatisfaction. They do, however, warn that quality perceptions may be impacted negatively if customers experience a bombardment of company e-mails. This line of reasoning leads to the following hypothesis:

$\mathrm{H}_{3}$ : The Responsiveness dimension of eService Quality will positively influence eSatisfaction.

\section{Customisation}

One of the major benefits of online technologies is that websites can be personalised to satisfy users' specific needs, and e-tailers should therefore strive to customise their services to fulfil their target market's requirements (Srinivasan, Anderson \& Ponnavolu, 2002: 42). Madu and Madu (2002: 252) acknowledge the importance of customisation by stating that online companies should differentiate themselves from their competitors by creating unique qualities that will make them stand out. They add that online users are looking primarily for convenience, and that e-tailers should offer customised products and services to satisfy this need. Customised information does not necessarily mean more information, but rather information of higher quality (Ha, 2004: 337).

A few portals, specifically in the tourism industry, require users to first log on (even where the service is free) before they can retrieve more detailed information. In this way the portal is able to track users' movements and preferences. Gummerus et al. (2004: 183) warn, however, that companies should carefully weigh the benefits of customisation allowed by data collection against the psychological costs to customers. They further state that gathering private data may frighten customers away. It is therefore important to find the influence of Customisation on eSatisfaction; the following hypothesis is therefore formulated:

$\mathrm{H}_{4}$ : The Customisation dimension of eService Quality will positively influence eSatisfaction. 


\section{Value-added services}

A few new eService Quality items were identified by browsing through various tourism portals and by investigating their service offerings. A new eService Quality dimension was created in order to group these items together and was called Value-added Services. The following items were classified under Value-added Services: map locators, end-user database, enduser newsletters and finally site statistics. The following hypothesis is postulated:

$\mathrm{H}_{5}$ : The Value-added Services dimension of eService Quality will positively influence eSatisfaction.

\section{2 eSatisfaction}

It is becoming increasingly more difficult for online companies to satisfy and bond with their customers, who are demanding ever better information and services, and showing less and less tolerance for malfunctioning sites (Reichheld \& Schefter, 2000: 113). Yang et al. (2003: 12) comment that it is therefore important to include their Internet-savvy customers in the development of commercial websites. They add that, if businesses were to design their sites according to the needs, wishes and preferences of their target customers, they would gain a competitive advantage over their rivals.

Earlier research by Jones and Sasser (1995: 93) proved that 'completely satisfied' customers are more loyal than 'merely satisfied' customers. They found that, in the automobile industry, even a slight drop from 'complete satisfaction' created an enormous drop in loyalty, to the extent that 'completely satisfied' customers were nearly 42 per cent more likely to be loyal than 'merely satisfied' customers. Strauss and Neuhaus (1997: 247) found similar results which point out that companies will have to start looking at the intensity of their customers' satisfaction levels. Managers must not be at ease with a good satisfaction score - some 20 per cent to 30 per cent of top customers (who gave a 5 out of 5 score for satisfaction) are inclined to switch (Mittal \& Lassar, 1998: 189).

The degree of satisfaction or dissatisfaction with the product choice on the part of the customer will therefore determine whether or not the consumer will purchase the product again or, if dissatisfied, will engage in a renewed search for alternatives (Kolesar \& Galbraith, 2000: 426). They add that satisfaction occurs when the product meets or exceeds the consumer's expectations, while dissatisfaction results when expectations are not met. But previous research by Johnston (1997: 112) argued that the causes of dissatisfaction are not necessarily the opposite of the causes of satisfaction. He explains that a bank that opens and closes erratically will lead to dissatisfied customers. However, a bank that opens and closes precisely on time does not automatically lead to delighted customers. It is therefore important to remove the causes of dissatisfaction for the ultimate goal of customer retention (Cho, Im, Hiltz \& Fjermestad, 2002: 648), as customers who have bad experiences tell approximately 11 people about them, compared to only six people when it comes to good experiences (Hart, Heskett \& Sasser, 1990: 153).

The only truly loyal customers are the totally satisfied customers (Jones \& Sasser, 1995: 91), and they are bound eventually to form emotional ties with a website (Reichheld et al., 2000: 174). Customer satisfaction is therefore considered a major driver of e-Loyalty (Gummerus et al., 2004: 181; Ribbink et al., 2004: 452; Semeijn et al., 2005: 191). According to Reichheld et al. (2000: 173), cyber customers are more willing to be loyal to reduce the risks of online shopping, hence the probability that they are going to stay with an online vendor is higher once they are satisfied. The following hypothesis is therefore stated:

$\mathrm{H}_{6}$ : eSatisfaction will positively influence eLoyalty.

\section{3 eValue}

Creating outstanding value, which is superior to what competitors offer, is the key to attaining a competitive advantage (Ravald \& Grönroos, 1996: 19; Slater, 1996: 80), and is normally achieved by means of clear-cut strategic positioning (Porter, 2001: 71). Value is defined as the results customers receive in relation to the total cost (both the price and other costs customers incur in acquiring the service) (Heskett et al., 1994: 166; McDougall \& 
Levesque, 2000: 394). Slater (1996: 81) adds that, if the benefits exceeded the costs, then a customer would at least consider purchasing the product. Earlier work from Zeithaml (1988: 3) does, however, differentiate between Value and Perceived Value. Perceived Value is defined as the consumer's overall assessment of the utility of a product based on perception of what is received and what is given. This definition makes Value much more subjective and individual. The chances of becoming successful will therefore be much higher if a company can provide Value in terms of reducing the customer's perceived sacrifice, so that the relationship costs are minimised and customer performance improved (Ravald \& Grönroos, 1996: 21).

Increasing the benefits for the customer means adding something to the core product that the customer perceives to be important, beneficial and of unique value, while the perceived sacrifice should include all the costs faced by the customer (Ravald \& Grönroos, 1996: 25). They warn, however, that far too many companies alienate themselves from their customers with unimportant add-ons that in some cases result in value-added that has nothing to do with the customers' actual needs. Porter (1996: 76) adds to this by stating that, too often, efforts to grow blur uniqueness, create compromises, reduce fit and ultimately undermine competitive advantage. He is further of the opinion that continuous improvement is unnecessary and leads only to imitation and homogeneity. Slater (1996) demonstrates that, because elements of competitive advantage will come and go, companies constantly have to focus on the following elements to create sustainable value: quality, service levels, cost control, speed of delivery, innovation and learning new cultures.

Value-added strategies should therefore be customer orientated (Ravald \& Grönroos, 1996: 21) and companies have to find out whether they are positively valued by customers and how their value perceptions affect Satisfaction and eLoyalty (Van Riel, Liljander \& Jurriëns, 2001: 362). Ravald and Grönroos (1996: 21) claim that the ultimate aim of adding more value is to enhance customer loyalty. Reichheld (1993: 64) further states that loyalty is earned by delivering superior value. But Value does not influence Loyalty only. Heskett et al. (1994: 166) report that Value is one of the main drivers and influencers of customer satisfaction. According to evidence generated by Zeithaml (1988: 4), customers who perceive that they have received 'value for money' are more satisfied than those who do not think they have. This leads to the following two hypotheses:

$\mathrm{H}_{7}$ : eValue will positively influence eLoyalty.

$\mathrm{H}_{8}$ : eValue will positively influence eSatisfaction.

\section{4 eLoyalty}

Anderson and Srinivasan (2003: 123), define eLoyalty as the customer's favourable attitude towards, for instance, an electronic business, resulting in repeat purchasing behaviour. As customers become more familiar with Internet technology, they tend to realise that the switching costs are low, making eLoyalty difficult to obtain (Olson \& Boyer, 2005: 78), which means that e-businesses have to focus on building strong ties of loyalty with their e-customers (Clarke, 2001: 164). However, Ribbink et al. (2004: 446) note that few companies seem to succeed in creating eLoyalty, and little is known about the mechanisms involved in generating customer loyalty on the Internet.

Building a highly loyal customer base cannot be done as an add-on; it must be integral to a company's basic business strategy (Reichheld, 1993: 64). Even though the retention of loyal customers is expensive and difficult to achieve, research shows that the benefits still outweigh the effort. Loyal customers are less price sensitive (Reichheld \& Sasser, 1990: 107) and will pay regular prices (Reichheld \& Schefter, 2000: 110) or accept premium prices (Reichheld \& Sasser, 1990: 107; Reichheld \& Schefter, 2000: 110). As the expense of pursuing new customers is reduced, so lower costs are incurred by the provider (Reichheld \& Schefter, 2000: 107; Reichheld, 2003: 3). There is greater longterm profitability for the firms (Ribbink et al., 2004: 446); loyal customers purchase more than do newly acquired customers (Reichheld \& Schefter, 2000: 106). Loyal customers generate an effective 'word of mouth' ripple 
effect that spreads to other potential customers (Gremler \& Brown, 1999: 276). These referred customers normally take advice from those who recommended the service to them, thus reducing the company's help-desk costs (Reichheld \& Schefter, 2000: 107). Finally, their tolerance about waiting on a temporarily unavailable service is also higher (Narayandas, 1998: 110). This is particularly important from the online perspective when a site goes down for short periods of time.

Traditional constraints on company size, like exhaustion of production economies of scale and increasing transportation costs as the firm tries to reach more customers, do not seem to apply to online portals (Meisel \& Sullivan, 2000: 486), However, Kung et al. (2002: 278) comment that, owing to the broad range of online clutter, extensive marketing and advertising expenditures are essential in attracting users to a site. Ha (2004: 336) found also that, in addition to online alliance advertising, e-marketers might have to carry out effective offline advertising. He illustrates this by reporting the success achieved by Amazon.com and Yahoo.com by significantly increasing their overall marketing budget, as well as shifting a majority of their media mix to traditional offline media like television, radio and outdoor advertising. In contrast to this, Reichheld and Schefter (2000: 110) provided evidence in their study that web 'loyalists' found sites mostly through referrals. In contrast, 'the butterflies' reported being lured by promotional discounts and general advertising. They further stated that, if a web company was spending most of its marketing budget on arbitrary banner ads and online coupons, with little investment in building communities and promoting referrals, it was probably building long-term losses into its customer base. Yang et al. (2003: 21) also prove that banner advertising and links with affiliates are not very effective for creating traffic. Capizzi and Ferguson (2005: 72) state that loyalty programmes, which were once a fairly easy way of acquiring loyal customers, are moving into a mature market, but Rowley (2005: 202), says, on the contrary, that it really depends on the objective of the loyalty scheme. She comments that if loyalty schemes are to be successful they must be managed at a strategic rather than operational level to build and sustain customer relationships.

It seems imperative that companies invest their marketing budgets to promote their services through offline advertising or to encourage referrals. Reichheld and Schefter (2000: 107) point out that Internet technology magnifies the lucrative effect of referrals because of the speed of emails, compared to word of mouth. They suggest that companies automate their referral processes so that their customers can easily send recommendations to acquaintances, while still accessing the company's website. By doing this, companies would generate profit much earlier in their life cycles. This would involve minor costs as far as referred customers are concerned. Ideally, a company should focus on getting its customers to become its marketing department (Reichheld, 2003: 3).

Figure 1 summarises the hypotheses in a conceptual model, which suggests that eService Quality dimensions influence eSatisfaction, which in turn influences eLoyalty. It also illustrates that eValue influences both eSatisfaction and eLoyalty. Five online eService Quality dimensions are considered in this article: User Interface, Security, Responsiveness, Customisation and Value-added services.

\section{Figure 1}

Summary of hypothesised conceptual framework

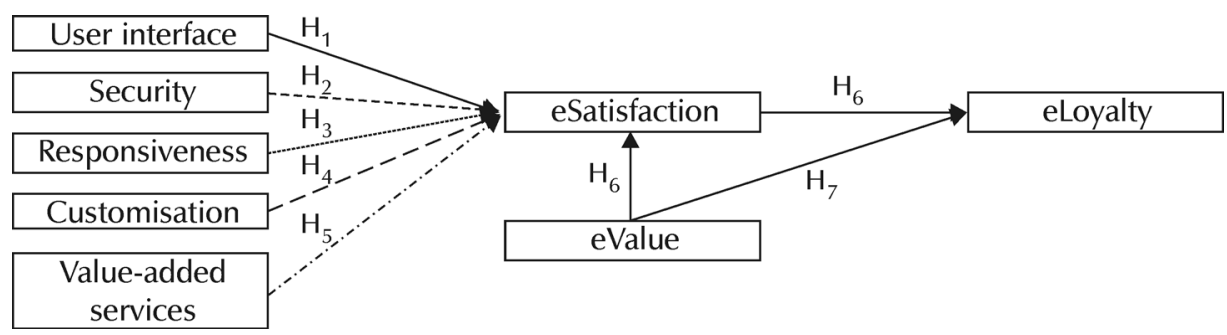


3

\section{Methodology}

\subsection{Sampling}

The target population of this study was South African tourist accommodation establishments who were advertising on online tourism portals during 2005. Contact details from 2500 establishments were collected from the Internet portals on which they were advertising, with coverage in all nine provinces. This list served as a sampling frame. An email was sent out with a clickable link to the online survey.

From the 108 valid responses, 46 had been advertising on their primary portal for less than two years, 37 for more than two years but less than four years, and 25 for more than four years. Most of the respondents were classified as bed $\&$ breakfast (38) or self-catering establishments (35), while 25 respondents were guesthouses and the rest (11) were hotels, lodges and backpackers. The majority of respondents' portals were asking a fixed annual fee (81), while only 28 of the respondents' portals used a commission-based strategy, normally taking between 10 per cent and 15 per cent of the booking fee. When evaluating the percentage of income they received from their portals, the following results were given: 45 respondents derived between 0 per cent and 19 per cent of their income from their portal; 36 respondents between 20 per cent and 39 per cent, and 28 respondents 40 per cent or more. Looking at the percentage of their international travellers, 35 respondents said that they received between 0 per cent and 19 per cent international travellers, 36 reported between 20 per cent and 59 per cent; and 37 reported that 60 per cent or higher of their guests were from foreign countries.

\subsection{Data collection}

Owing to the unpredictable nature of email surveys, pre-testing was carried out with a focus group of five research survey specialists. Prior to this, extensive research was done to investigate various tourism portal service offerings. The email survey was sent out during October 2005. A personalised branded HTML email, which was connected to a competition, was sent to all 2500 establishments. Once they received the email, they had to click on the link to open the online survey. When completing the online study, each establishment was asked to answer the questions by drawing on the cumulative experience of their interaction with their primary online tourism portal. A reminder email was sent out a week after the first email, to those establishments that had not yet responded. A total of 154 responses (6 per cent response rate) were received, of which only 109 were valid, as the other 45 respondents had completed the questionnaire with reference to their own website instead of their primary portal site. Time and cost limitations prohibited the researchers from repeatedly soliciting non-respondents to increase the overall response rate.

\subsection{Measurement}

The items used to measure the eService Quality construct were based on previous research by Bansal et al. (2004); Feinberg and Kadam (2002); Gummerus et al. (2004); Jun et al. (2004); Keating et al. (2003); Luarn and Lin (2003); Madu and Madu (2002); Ribbink et al. (2004) and Yang et al. (2003). The items were adapted to the specific characteristics of the research setting-online tourism portals. Extra questions were included to cover certain specific tourism portal quality variables, including the quality of the map locators, newsletters, client databases, site statistics, and the layout and quality of the search pages. All of the 18 independent eService Quality variables were measured in terms of the extent to which the participants agreed with the statements on a five-point Likert scale, ranging from strongly disagree $=1$ to strongly agree $=5$. These variables were divided into 5 dimensions, which included the following: User Interface (6 questions); Customisation (2 questions); Responsiveness (3 questions); Security (3 questions) and finally Value-add services (4 questions). The complete text of measurement items used is available in Annexure A.

Reliability is the extent to which a measure is free from variable errors (Nunnally, 1978: 245). The reliability of the independent eService Quality construct was assessed with respect 
to internal consistency. Cronbach's alpha is a measure of the reliability of a set of two or more construct indicators, while an alpha coefficient that exceeds 0.7 is seen as an acceptable reliability (Bland \& Altman, 1997: 170; Hair, Anderson, Tatham \& Black, 1995: 130). The Cronbach alpha coefficient for the eService Quality construct of this study was 0.926 , indicating acceptable internal consistency reliability. In order to deal with the 'not applicable' answers, mean substitution was applied. None of the items was selected for deletion.

Three items measured the eSatisfaction construct (Ha, 2004: 332; Ribbink et al., 2004: 449). A five-point Likert scale was used in all three questions: strongly disagree $=1$ to strongly agree $=5$ and included the following statements: I am satisfied to be associated with this portal; I am still satisfied with my decision to advertise on this portal; I am still satisfied with the overall offering of this portal. The Cronbach alpha coefficient for the eSatisfaction construct was 0.937 , which indicates acceptable internal consistency reliability.

Most of the literature on Value suggests a multiple dimension scale (Pura, 2005: 521), while other writing focuses on a single-item scale (Bolton \& Drew, 1991: 382; Van Riel et al., 2001: 367). In this article, three variables that measure Value were formulated to fit the research setting. Apart from the classical variable stating that value for money should be generated, Value was also defined in terms of cost vs. Value-added services, as well as an item that covered awareness and reach. All three were measured with a five-point Likert scale, ranging from strongly disagree $=1$ to strongly agree $=5$. The Cronbach alpha coefficient for the eValue construct was 0.936 , which indicates acceptable internal consistency reliability.

The eLoyalty construct was measured using an 11-point Likert scale, ranging from not likely at all $=0$ to extremely likely $=10$. Three items (Reichheld, 2003: 5) were included, focusing on the likelihood of the portal being recommended; the likelihood of continuous use of the portal; and the likelihood of using additional services offered by the portal.

\section{4}

\section{Research results}

Most of the eService Quality items had to be adjusted to fit the characteristics of the research setting and it is therefore crucial to validate these items first. Secondly it is important to judge whether the elements were grouped correctly.

A principal factor analysis with Varimaxrotation is conducted to assess convergence within and discrepancy between scales. Factor analysis group together items that produce a similar response in a survey, implying that these items are measuring the same construct and a Varimaxrotation ensures that the factors generated do not correlate with each other (Davies \& Vinhas, 2002: 149). Eigenvalues are direct indices of how much of the total item variance is accounted for by a particular component (Hair et al., 1995: 131). The larger the eigenvalue, the more the variance in the item is explained by that component (Kline, 1993: 30). The Varimax-rotated factor loadings matrix is presented in Table 1 . The results yielded four factors with an eigenvalue of 11.9 which accounted for 66.4 per cent of the total variance.

\section{Table 1}

Factor analysis for service quality items

\begin{tabular}{|l|c|c|c|c|l|}
\hline & Eigenvalue & \% total & $\begin{array}{c}\text { Cumulative } \\
\text { eigenvalue }\end{array}$ & $\begin{array}{c}\text { Cumulative of } \\
\text { \% total }\end{array}$ & \\
\hline Factor 1 & 8.21 & 45.61 & 8.21 & 45.61 & \\
Factor 2 & 1.34 & 7.43 & 9.55 & 53.03 & \\
Factor 3 & 1.26 & 7.00 & 10.81 & 60.04 & \\
Factor 4 & 1.14 & 6.31 & 11.94 & 66.35 & $\begin{array}{l}\text { Cumulative } \\
\text { explained } \\
\text { variance }\end{array}$ \\
\hline
\end{tabular}


Table 2 summarises the details of these factor loadings. Among the four factors, Factor 1 corresponded to a new group name of Effective Communication (six items), Factor 2 to Site Interface and Advertising (seven items), Factor 3 to Value-add (three items) and Factor 4 to Customisation (two items). Furthermore, almost all of the factor loadings were larger than 0.5 , except for 'easy to find site through major search engines' ( 0.50$)$, indicating good validity, as well as a high degree of individual item reliability.

According to the factor loadings, the original eService quality dimensions of Security and Responsiveness have merged to form Factor 1 or Effective Communication. This factor has the highest eigenvalue, explaining 45.61 per cent of the total variance. The 'easy to find site through major search engines'-item has also moved from the original Value-added dimension to the new User Interface and Marketing dimension. Finally the 'useful site statistics' item in Factor 3 has also showed a strong appearance in Factor 2 , and it is noteworthy that both loadings are greater than 0.50 . This item should, however, not be included in the final factor solution. The incidence of two-item factors (Factors 3 and 4) is problematic but it is argued to be acceptable for an exploratory study of this nature.

Table 2

Four eService quality factor loadings

\begin{tabular}{|c|c|c|c|c|c|}
\hline & & $\begin{array}{c}\text { Factor } \\
1\end{array}$ & $\begin{array}{c}\text { Factor } \\
2\end{array}$ & $\begin{array}{c}\text { Factor } \\
3\end{array}$ & $\begin{array}{c}\text { Factor } \\
4\end{array}$ \\
\hline \multirow{6}{*}{$\begin{array}{l}\text { Effective } \\
\text { communi- } \\
\text { cation }\end{array}$} & Privacy \& security policies & 0.79 & 0.29 & 0.15 & 0.02 \\
\hline & Trustworthiness & 0.74 & 0.50 & 0.11 & 0.06 \\
\hline & Personal \& professional correspondence & 0.73 & 0.23 & 0.18 & 0.32 \\
\hline & Responsiveness to communication & 0.70 & 0.16 & 0.16 & 0.33 \\
\hline & Quick \& effective complaint handling & 0.67 & 0.18 & 0.27 & 0.26 \\
\hline & Secure site and correspondence & 0.64 & 0.37 & 0.25 & -0.03 \\
\hline \multirow{7}{*}{$\begin{array}{l}\text { User } \\
\text { interface } \\
\text { and } \\
\text { marketing }\end{array}$} & Portal aesthetics & 0.33 & 0.66 & 0.12 & 0.16 \\
\hline & Page template that complements image & 0.33 & 0.77 & 0.06 & 0.15 \\
\hline & Search page layout to distinguish between offerings & 0.03 & 0.72 & 0.17 & 0.37 \\
\hline & Energy \& buzz of portal & 0.30 & 0.68 & 0.19 & 0.26 \\
\hline & Navigation structure & 0.29 & 0.57 & 0.24 & 0.10 \\
\hline & Quality of map locators & 0.28 & 0.54 & -0.02 & 0.11 \\
\hline & Easy to find site through major search engines $* *$ & 0.21 & $0.50^{*}$ & 0.36 & 0.15 \\
\hline \multirow[t]{3}{*}{ Value-add } & High standard of Newsletter & 0.22 & 0.05 & 0.86 & 0.17 \\
\hline & High standard of end user database & 0.34 & 0.18 & 0.75 & 0.23 \\
\hline & Useful site statistics $* * *$ & 0.08 & 0.51 & 0.58 & -0.06 \\
\hline \multirow{2}{*}{$\begin{array}{l}\text { Customisa- } \\
\text { tion }\end{array}$} & Ease of adding a page & 0.14 & 0.31 & 0.11 & 0.84 \\
\hline & Ease of updating page details & 0.29 & 0.22 & 0.19 & 0.80 \\
\hline
\end{tabular}

$* \quad$ Factor loading $=0.50$, which is border line for item reliability

** Indication that item has moved from the original Value-add dimension to the new user interface and marketing dimension.

*** Small difference between factor loading in Factor 2 and Factor 3 - both values are significant, as $>0.5$ 
The hypothesised structural model was tested using the Bentler Comparative Fit Index (CFI) and Bentler-Bonett Non-Normed Fit Index (NNFI). According to Bollen and Long (1993: 42) it is essential for more than one fit index to be used to ensure that meaningful conclusions on model fit can be reached. The CFI and the NNFI indices are generally preferred, as they are less likely to produce biased estimates in small samples. Values over 0.9 on both the NNFI and CFI indicate an acceptable fit (Hatcher, 1994: 291). Ding, Velicer and Harlow (1995: 139) concurred, and concluded from their experiments that NNFI were independent of sample size, whereas CFI was affected to a small degree by sample size.

Results of the structural model revealed a CFI value of 0.723 and a NNFI value of 0.682 . Even though this does not indicate a good model fit, the model is still statistically significant $(\mathrm{p}<0.05)$. Figure 2 presents the model with all its significant relationships, as well as the parameters and t-values of each relationship.

The $\mathrm{H}_{1}, \mathrm{H}_{2}, \mathrm{H}_{3}, \mathrm{H}_{4}$ and $\mathrm{H}_{5}$ hypotheses investigated the relationship between the eService quality dimensions (User Interface, Security, Responsiveness, Customisation and
Value-added) and eSatisfaction. User Interface ( parameter $=0.541 ; \mathrm{t}=7.514)$, Security and Responsiveness (which merged as one factor, namely Effective Communication) with parameter $=0.236, \mathrm{t}=2.946$ ) all indicated a positive relationship with eSatisfaction and therefore the $\mathrm{H}_{1}, \mathrm{H}_{2}$ and $\mathrm{H}_{3}$ hypotheses were supported. Hypotheses $\mathrm{H}_{4}$ and $\mathrm{H}_{5}$ were rejected, as no relationship was found between the Valueadded Service dimension and the eSatisfaction construct or the Customisation dimension and the eSatisfaction construct. Noteworthy is the fact that both of these two dimensions have a positive relationship with the eValue construct. These relationships are illustrated in Figure 2 as dotted lines. The $\mathrm{H}_{6}$ hypothesis, predicting a positive relationship between eSatisfaction and eLoyalty, was supported. Results revealed that the path between eSatisfaction and eLoyalty was indeed positive with a strong relationship, indicating a parameter value of 0.547 and $\mathrm{t}=3.845 . \mathrm{H}_{7}$ and $\mathrm{H}_{8}$ proposed relationships between eValue and eLoyalty and eValue and eSatisfaction respectively. The $\mathrm{H}_{7}$ hypothesis was supported by a relationship of 0.284 and $t=3.524$, but there was no significant relationship between eSatisfaction and $e$ Value, and $\mathrm{H}_{8}$ was therefore rejected.

Figure 2

Structural model indicating all significant relationships

Portal aesthetics
Page template that complements image
Search page layout
Energy \& buzz of portal
Navigation structure
Quality of map locations

Find through major search engines

Privacy \& security policies Trustworthiness

Personal \& professional correspondence Responsiveness to communication Quick \& effective complaint handling Secure site and correspondence High standard of Newsletter High standard of end user database

Ease of adding a page Ease of updating page details

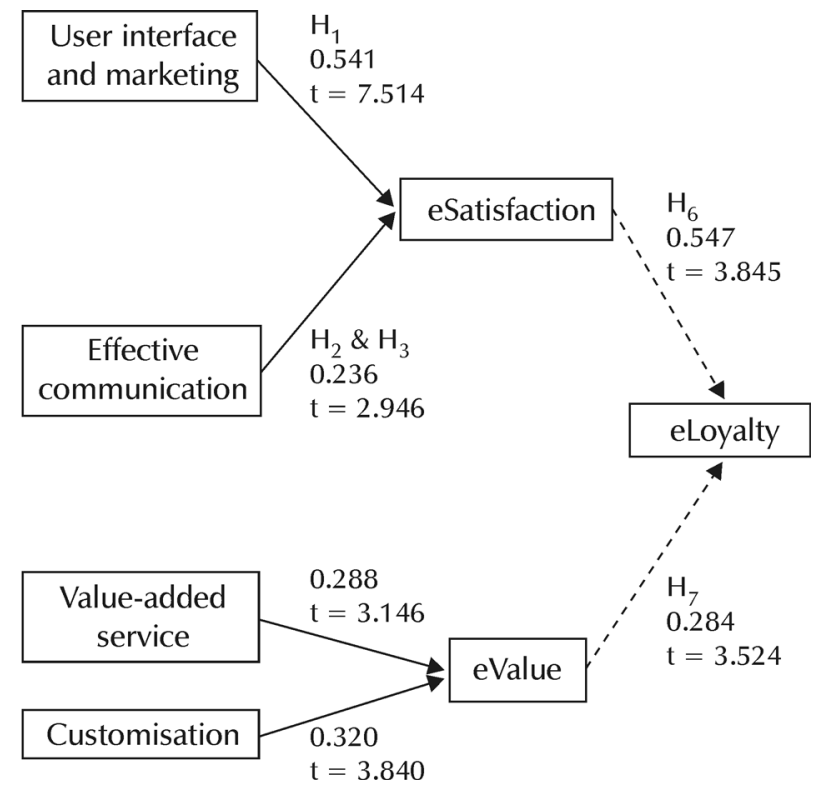


5

\section{Conclusions and managerial implications}

Most of the existing Internet literature has focused on the general Internet end user/ customer, while very little research has been done on exploring how portal suppliers influence their profitability. Previous research has already proved that customer loyalty directly influences profitability (Reichheld, 2003: 2). This article therefore aimed at determining which elements are most important in acquiring and developing a loyal supplier base, which, in most cases, is the main source of income for online portals. This article proposed a model that is specifically created for the online tourism portal industry, but it can be applied also to other portal industries with little modification to the eService quality items. Data was collected from an email survey sent to tourism establishments and used to validate the proposed model.

The proposed model is in line with models of previous research (Ribbink et al., 2004: 452), which state that eService Quality influences eSatisfaction, which in turn influences eLoyalty. The results conclude that the proposed model does not prove significant, although some of the relationships in the model are confirmed to be highly significant. The model further illustrates that some eService Quality dimensions influence eValue directly (without a double path to eSatisfaction) and that eValue also has a strong direct influence on eLoyalty, but no influence on eSatisfaction.

Four significant eService quality dimensions have been identified through factor analysis, and include the following: Effective Communication, User Interface and Marketing, Value-add Service and Customisation. The effective communication, User Interface and Marketing dimensions had a significant and positive influence on eSatisfaction, whereas the Valueadded Services and Customisation dimensions had a significant and positive influence on eValue. This is fairly unusual, as many studies have suggested that all Service Quality dimensions influence Satisfaction, and only in some instances do dimensions have a double path to another variable (as in the case of
eTrust, in Ribbink et al., 2004: 453). According to McDougall and Levesque (2000: 403), eValue influences eSatisfaction. The results of this study indicate, however, that eValue had no influence on eSatisfaction, which might be a consequence of some of the eService Quality dimensions that either only influenced eSatisfaction or eValue. Another possible explanation might be that Value's influence on Satisfaction might depend on the industry or research context.

The merge of the original Security and Responsiveness dimensions, which created the new Effective Communications dimension, was also unexpected, but very significant, as this new factor loading was the strongest, with 45.61 per cent of the total variance. This article therefore suggests that online companies should first address the issue of security and privacy both to protect personal and transactional data, and to have a highly visible privacy policy. One example of increasing trustworthiness might be for companies like VeriSign or Thawte to provide SSL certificates on the website. The human element of effective communication is visible through communication channels (whether email or telephone) and should also receive high priority. The findings of this study show that all communication should appear personal and professional, and should happen in a timely manner. This could be dealt with by making sure that support staff are customerfocused; a log should be kept of all incoming and outgoing queries, and all correspondence should be professionally branded.

The User Interface and Marketing dimension indicated a strong relationship with eSatisfaction (Ribbink et al., 2004: 453), so this dimension should receive a high priority status. Portal managers should therefore spend enough time and finance on designing their sites in such a way that Internet users would be intrigued and encouraged to visit them. Time should also be spent on the establishment of page templates, as well as on the layout of the search pages, enabling users to easily establish the difference between competitor offerings. Ribbink et al. (2004: 453) also concluded that, if online companies wanted to substantially increase their eSatisfaction, then they should provide an attractive user interface. 
The high factor loadings of Customisation's 'ease of adding a page' and 'ease of updating page details', as well as the strong relationship between this dimension and eValue is very significant. The results suggest that portal managers ought to consider the importance of establishments' easily manipulating their details. Further, portal managers need to simplify this process as much as possible. The strong relationship also implies that Customisation is very important, and that portals receiving a significant income stream from updating establishment page details might have to rethink their strategy.

The strong relationship between the Valueadded dimension and the eValue construct also shows that establishments value the 'extra' valueadded elements. This is understandable, as the newsletter and database items in this dimension focus exclusively on increasing awareness of the establishment on the part of the portal target market, which will effectively influence the amount of leads they receive. On the other hand, site statistics are also important, as efficient and useful statistics allow establishments to assess the value provided by the portal. This relationship therefore shows that portals cannot focus only on increasing their own income, but will, in fact, have to be responsible for increasing their customers' income.

\section{6 \\ Limitations and suggestions for further research}

Although this article provides some exploratory insight into how online tourism portals could increase loyalty and subsequent profit margins, it has certain limitations. The greatest is that of the sample size. Only 109 respondents participated in this study and a larger sample size might have realised more significant results. This might also have had a substantial influence on accepting the proposed model. It is further possible that the word 'still' in the satisfaction questions might have influenced some of the respondents. Future research should avoid the inclusion of this word and similar misnomers.

Further research could generate more precise indicators, helping online portals address their customers' needs more effectively. They could, for instance, identify the specific eService Quality items (instead of overall dimensions) that influence eSatisfaction and eValue more directly.

\section{References}

1 ALBA, J.; LYNCH, J.; WEITZ, B.; JANISZEWSKI, C.; LUTZ, R.; SAWYER, A. \& WOOD, S. (1997) "Interactive home shopping: Consumer, retailer and manufacturer incentives to participate in electronic marketplaces", Journal of Marketing, 61(July): 38-53.

2 ANDERSON, R.E. \& SRINIVASAN, S.S. (2003) "E-satisfaction and e-loyalty: A contingency framework", Psychology and Marketing, 20(2): 123-138.

3 BANSAL, H.S.; MCDOUGALL, G.H.G.; DIKOLLI, S.S. \& SEDATOLE, K.L. (2004)

"Relating e-satisfaction to behavioural outcomes: an empirical study", Journal of Services Marketing, 18(4): 290-302.

4 BITNER, M.J. (1992) "Servicescapes: The impact of physical surroundings on customers and employees", Journal of Marketing, 56(April): 57-71.

5 BLAND, J.M. \& ALTMAN, D.G. (1997)

"Statistics notes: Cronbach's alpha", British Medical Journal, 310: 170.

6 BOLLEN, K.A. \& LONG, J.S. (1993) Testing Structural Equation Models, Sage: Newbury Park, CA.

7 BOLTON, R.N. \& DREW, J.H. (1991) “A multistage model of customers' assessments of service quality and value", Journal of Consumer Research, 17(March): 375-384.

8 CAPIZZI, M.T. \& FERGUSON, R. (2005) "Loyalty trends for the twenty first century", Journal of Consumer Marketing, 22(2): 72-80.

9 CHO, Y.; IM, I.; HILTZ, R. \& FJERMESTAD, J. (2002) "The effects of post-purchase evaluation factors on line vs. offline customer complaining behaviour: Implications for customer loyalty", Advances in Consumer Research, 29(1): 318-326.

10 CLARKE, K. (2001) "What price on loyalty when a brand switch is just a click away?", Qualitative Market Research: An International Journal, 4(3): 160-168.

11 DAVIES, G. \& VINHAS, R. (2002) Corporate Reputation and Competitiveness. Routledge: New York.

12 DING, L.; VELICER, W.F. \& HARLOW, L.L. (1995) "Effects of estimation methods, number of indicators per factor, and improper solutions on structural equation modelling fit indices", Structural Equation Modelling, 2(2): 119-144.

13 FEINBERG, R. \& KADAM, R. (2002) "E-CRM web service attributes as determinants of customer 
satisfaction with retail web sites", International Journal of Service Industry Management, 13(5): 432-451.

14 GREMLER, D. \& BROWN, S. (1999) The loyalty ripple effect: Appreciating the full value of customers, International Journal of Service Industry Management, 10(3): 271-291.

15 GRÖNROOS, C.; HEINONEN, F.; ISONIEMI, K. \& LINDHOLM, M. (2000) "The NetOffer model: A case example from the virtual marketspace”, Management Decision, 38(4): 243-252.

16 GUMMERUS, J.; LILJANDER, V.; PURA, M. \& VAN RIEL, A. (2004) "Customer loyalty to content-based web sites: The case of an online healthcare service", Journal of Services Marketing, 18(3): 175-186.

17 HA, H. (2004) "Factors influencing consumer perceptions of brand trust online", Journal of Product \& Brand Management, 13(5): 329-342.

18 HAIR. J.F.; ANDERSON, R.E.; TATHAM, R.L. \& BLACK, W.C. (1995) Multivariate Data Analysis with Readings. Prentice-Hall: New York.

19 HART, C., HESKETT, J. \& SASSER, W. (1990) "The profitable art of service recovery", Harvard Business Review, July-August: 148-156.

20 HATCHER, L. (1994) A Step-by-step approach to using the SAS System for Factor Analysis and Structural Equation Modelling. SAS Publishing: Cary.

21 HESKETT, J.; JONES, T.; LOVEMAN, G.; SASSER, W. \& SCHLESINGER, L. (1994) "Putting the service-profit chain to work", Harvard Business Review, March-April: 164-174.

22 JAYAWARDHENA, C. \& FOLEY, P. (2000) "Changes in the banking sector - The case of Internet banking in the UK", Internet Research: Electronic Networking Applications and Policy, 10(1): 19-30.

23 JIANG, P. \& ROSENBLOOM, B. (2005) "Customer intention to return online: Price perception, attribute-level performance, and satisfaction unfolding over time", European Journal of Marketing, 39(1/2): 150-174.

24 JOHNSTON, R. (1997) "Identifying the critical determinants of service quality in retail banking: Importance and effect", International Journal of Bank Marketing, 15(4): 111-16.

25 JONES, T.O. \& SASSER, W.E. (1995) "Why satisfied customers defect", Harvard Business Review, November-December: 88-99.

26 JUN, M.; YANG, Z. \& KIM, D. (2004) "Customers' perceptions of online retailing service quality and their satisfaction", International Journal of Quality \& Reliability Management, 21(8): 817-840.
27 KAYNAMA, S.A. \& BLACK, C.I. (2000) “A proposal to assess the service quality of online travel agencies: an exploratory study", Journal of Professional Services Marketing, 21(1): 63-88.

28 KEATING, B.; RUGIMBANA, R. \& QUAZI, A. (2003) "Differentiating between service quality and relationship quality in cyberspace", Managing Service Quality, 13(3): 217-232.

29 KLINE, P. (1993) An Easy Guide to Factor Analysis. Routledge: New York.

30 KOLESAR, M.B. \& GALBRAITH, R.W. (2000) "A services-marketing perspective on eretailing”, Internet Research: Electronic Networking Applications and Policy, 10(5): 424-438.

31 KUNG, M.; MONROE, K.B. \& COX, J.L. (2002) "Pricing on the Internet", Journal of Product \& Brand Management, 11(5): 274-287.

32 LASSAR, W.M. \& DANDAPANI, K. (2003) "Media perceptions and their impact on web site quality”, International Journal of Bank Marketing, 21(1): 38-47.

33 LEE-KELLEY, L.; GILBERT, D. \& MANNICOM, R. (2003) "How e-CRM can enhance customer loyalty. Marketing Intelligence \& Planning, 21(4): 239-248.

34 LEE, C.K. \& HU, C. (2004) "Online complaints - analyzing hotel customers' E-Complaints from an internet complaint forum”, Journal of Travel \& Tourism Marketing 17(2/3): 167-181.

35 LUARN, P. \& LIN, H. (2003) "A customer loyalty model for e-service context", Journal of Electronic Commerce Research, 4(4): 156-167.

36 LYNCH, J.G. \& ARIELY, D. (2000) "Wine online: Search costs affect competition on price, quality, and distribution", Marketing Science, 19(1): 83-103.

37 MADU, C.N. \& MADU, A.A. (2002) "Dimensions of e-quality”, International Journal of Quality \& Reliability Management, 19(3): 246-258.

38 MCDOUGALL, G.H.G. \& LEVESQUE, T. (2000) "Customer satisfaction with services: Putting perceived value into equation", Journal of Services Marketing, 14(5): 392-410.

39 MEISEL, J.B. \& SULLIVAN, T.S. (2000) "Portals: the new media companies", Camford Info, 2(5): 477-486.

40 MILLER, B. (2004) "Building E-loyalty of lodging brands: Avoiding brand erosion", Journal of Travel \&Tourism Marketing, 17(2/3): 133-142.

41 MITTAL, B. \& LASSAR, W.M. (1998) "Why do customers switch? The dynamics of satisfaction vs. loyalty", Journal of Services Marketing, 12(3): 177-194.

42 NARAYANDAS, D. (1998) "Measuring and managing the benefits of customer retention: 
An empirical investigation", Journal of Service

Research, 1(2): 108-128.

43 NUNNALLY, J. (1978) Psychometric Theory. McGraw-Hill: New York, NY.

44 OLSON, J.R. \& BOYER, K.K. (2005) "Internet ticketing in a non-for-profit, service organisation: Building customer loyalty", International Journal of Operations \& Production Management, 25(1): 74-92.

45 PORTER. M.E. (2001) "Strategy and the Internet", Harvard Business Review, March: 62-78.

46 PORTER, M.E. (1996) "What is a strategy?", Harvard Business Review, November-December: 61-78.

47 PURA, M. (2005) "Linking perceived value and loyalty in location-based mobile services", Managing Service Quality, 15(6: 509-538).

48 RAVALD, A. \& GRÖNROOS, C. (1996) "The value concept and relationship marketing", European Journal of Marketing, 30(2): 19-30.

49 REIBSTEIN, D.J. (2002) "What attracts customers to online stores, and what keeps them coming back", Journal of the Academy of Marketing Science, 30(4): 465-73.

50 REICHHELD, F.F. \& SASSER, W.E. (1990) "Zero defections: Quality comes to services", Harvard Business Review, September-October: 105-111.

51 REICHHELD, F.F. (1993) "Loyalty based management", Harvard Business Review, MarchApril: 64-73.

52 REICHHELD, F.F. \& SCHEFTER, P. (2000) "Eloyalty: Your secret weapon on the web", Harvard Business Review, July-August: 105-113.

53 REICHHELD, F.F.; MARKEY, R.G. \& HOPTON, C. (2000) "E-customer loyalty - applying the traditional rules of business for online success. European Business Journal, 12(4): 173-179.

54 REICHHELD, F.F. (2003) "The one number you need to grow", Harvard Business Review, December(Reprint R0312C): 1-9.

55 RIBBINK, D.; VAN RIEL, A.C.R.; LILJANDER, V. \& STREUKENS, S. (2004) "Comfort your online customer: quality, trust and loyalty on the Internet", Managing Service Quality, 14(6): 446-456.

56 ROWLEY, J. (2005) "Building brand webs. Customer relationship management through the Tesco Club card loyalty scheme”, International Journal of Retail and Distribution Management, 33(3): 194-206

57 SEMEIJN, J.; VAN RIEL, A.C.R.; VAN BIRGELEN, M.J.H. \& STREUKENS, S. (2005) "E-services and offline fulfilment: how e-loyalty is created”, Managing Service Quality, 15(2): 182-194.
58 SLATER, S.F. (1996) "The challenge of sustaining competitive advantage", Industrial Marketing Management, 25(1): 79-86.

59 SRINIVASAN, S.S.; ANDERSON, R.E. \& PONNAVOLU, K. (2002) "Customer loyalty in e-commerce: An exploration of its antecedents and consequences", Journal of Retailing, 78(1): 41-51.

60 STANFORD, J.; TAUBER, E.R.; FOGG, B.J. \& MARABLE, L. (2002) "Experts vs. online consumers: a comparative credibility study of health and finance web sites", Consumer Reports WebWatch, October. [online]Available from: http://64.78.25.46/view-article. $\mathrm{cfm}$ ?id=10156\&at $=510$ [Accessed: 2005-11-23].

61 STORBACKA, K.; STRANDVIK, T. \& GRÖNROOS, C. (1994) "Managing customer relationships for profit: The dynamics of relationship quality", International Journal of Service Industry Management, 5(5): 21-38.

62 STOREY, C.D. \& EASINGWOOD, C.J. (1996) "Determinants of new product performance. A study in the financial services sector", International Journal of Service Industry Management, 7(1): 32-55.

63 STRAUSS, B. \& NEUHAUS, P. (1997) "The qualitative satisfaction model", International Journal of Service Industry Management, 8(3): 236-249.

64 SURESHCHANDAR, G.S.; RAJENDRAN, C. \& ANANTHARAMAN, R.N. (2002) "The relationship between service quality and customer satisfaction - a factor specific approach", Journal of Services Marketing, 16(4): 363-379.

65 TROCCHIA, P.J. \& JANDA, S. (2003) "How do customers evaluate Internet retail service quality?", Journal of Service Marketing, 17(3): 243-253.

66 VAN RIEL, A.C.R.; LILJANDER, V. \& JURRIËNS, P. (2001) "Exploring consumers' evaluations of e-services: A portal site", International Journal of Service Industry Management, 12(4): 359-377.

67 WOLFINBARGER, M. \& GILLY, M.C. (2003)

"EtailQ: dimensionalizing, measuring and predicting etail quality”, Journal of Retailing, 79(3): 183-198.

68 YANG, X.; AHMED, Z.U.; GHINGOLD, M.; BOON, S.; MEI, T.S. \& HWA, L.L. (2003) "Consumer preferences for commercial web site design: an Asia-Pacific perspective", Journal of Consumer Marketing, 20(1): 10-27.

69 YANG, Z., PETERSON, R.T. \& CAI, S. (2003) "Service quality dimensions of Internet retailing: an exploratory analysis", Journal of Services Marketing, 17(7): 685-700. 
70 YOO, B. \& DONTHU, N. (2001) "Developing a scale to measure the perceived quality of Internet shopping sites (SITEQUAL)", Quarterly Journal of Electronic Commerce, 2(1): 31-47.

71 ZEITHAML, V.A. (1988) "Consumer perceptions of price, quality and value: A means-end model and synthesis of evidence", Journal of Marketing, 52(July): 2-22.
72 ZEITHAML, V.A. (2002) "Service excellence in electronic channels", Managing Service Quality, 12(3): 135-138.

73 ZEITHAML, V.A.; PARASURAMAN, A. \& MALHOTRA, A. (2002) "Service quality delivery through web sites: A critical review of extant knowledge", Journal of the Academy of Marketing Science, 30(4): 362-375.

\section{Annexure A}

\section{eService Quality (user interface)}

1. Customers or potential customers find it very easy to find my page through the portal's navigation structure

2. The overall portal aesthetics (look and feel, colours, layout and images) are very professional and have a positive influence on potential customers

3. The portal creates enough buzz and energy to help attract new customers

4. The quality and usability of the map locators are created to a very high standard. The portal creates enough buzz and energy to help attract new customers

5. Due to the easy and simplified layout of the search results page, my clients find it very easy to distinguish between my offering and competitor offerings

6. My portal has created a very professional initial page for me that complements my establishment's image

\section{eService Quality (customisation)}

7. I found the process to add my page onto the portal very easy and intuitive

8. I found the process to update my page details very easy and intuitive

\section{Service Quality (security)}

9. I feel that this portal is very trustworthy

10. I feel comfortable about the portal's privacy and security policies

11. I feel that my customer or potential customer's information is very secure when corresponding through the site

\section{eService Quality (responsiveness)}

12. The portal always responds promptly through all communication mediums

13. All complaints are handled quickly and effectively

14. The communication from the portal is always personalised and professional

eService Quality (value add services)

15. The quality of newsletters from the portal to potential customers are of a very high standard

16. The portal's customer database to whom the newsletter is sent to, is of a very high standard

17. It is very easy to find the portal site through the major search engine sites

18. The portal provides me with useful site statistics

eValue

19. The awareness and reach that I have received for my establishment through the portal site have been very good

20. Advertising on this portal provides value in terms of cost vs. income generation

21. Advertising on this portal provides value in terms of cost vs. value added services 


\section{eSatisfaction}

22. I am satisfied to be associated with this portal

23. I am still satisfied with my decision to advertise on this portal

Five-point Likert scale from

Disagree $=1$ to

24. I am still satisfied with the overall offering of this portal

eLoyalty

25. What is the likelihood that you would recommend this portal to your colleagues within the tourism industry as an advertising medium?

26. What is the likelihood that you would continue using this site as your portal?

27. What is the likelihood that you would use more of the services of the portal (for

Agree $=5$

example, add more advertisements, use additional value add services, etc.)?

Eleven-point scale with Not

likely at all $=0$,

Neutral $=5$ and

Extremely likely

$=10$ 